\title{
EFFICACY OF MASS TRAPPING OF TOMATO LEAFMINER (TUTA ABSOLUTA) WITH DIFFERENT TYPES AND COLOURS OF TRAPS IN OPEN- FIELD TOMATO
}

\author{
POLAT, B.
Çanakkale Onsekiz Mart University, Faculty of Agriculture, Department of Plant Protection 17020 Canakkale, Turkey \\ (e-mail: brkpolat@gmail.com; phone: +90-286-218-0018; fax: +90-286-218-0545)
}

(Received $6^{\text {th }}$ Sep 2019; accepted $15^{\text {th }}$ Nov 2019)

\begin{abstract}
As a limiting factor on tomato production, tomato leafminer Tuta absoluta (Meyrick, 1917) (Lepidoptera: Gelechiidae) has recently been considered as the main tomato pest. Different control methods should be considered for integrated pest management. This study was carried out to control T. absoluta by using pheromones and traps of five different colours (red, yellow, blue, white, black) and three different types (ferolite, water pan, roll) in combination at trial plots in Dardanos and Dumrek and Cıplak villages in Çanakkale province, Turkey. A randomized plot experimental design was implemented and traps were controlled and counted twice a week. Ferolite traps were determined to have the most success in capturing adults, followed by water and roll traps. The highest number of adults was captured with the colours black and white regardless of trap type, whereas the lowest number of adults was captured with yellow traps. It was observed upon comparing the capture rates of T. absoluta adults subject to trap type that $49 \%$ of the adults were counted in the ferolite traps. Water pans and roll traps followed the ferolite trap with $38 \%$ and $13 \%$, respectively. Results indicate that mass trapping is effective in reducing the pest population in open-field tomato cultivars.
\end{abstract}

Keywords: Çanakkale, light trap, water pan trap, roll trap, pest management

\section{Introduction}

The tomato leafminer Tuta absoluta (Meyrick, 1917) (Lepidoptera: Gelechiidae) of South American origin was first encountered in Europe in 2006 in tomatoes cultivated under greenhouse conditions. The pest had spread rapidly causing significant damage in countries located in the Mediterranean basin (Urbaneja et al., 2007; Zappalà et al., 2013). It was first discovered in Turkey in open-field tomatoes in 2009 (K1l1c, 2010; Kasap et al., 2011). Tuta absoluta is a multivoltine and oligophagous pest and may damage many solanaceous crops (Torres et al., 2001; Desneux et al., 2010; Portakaldal1 et al., 2013; Gozel and Kasap, 2015; Uzun et al., 2015). The larvae of this invasive pest feed on all above-ground parts of the tomato plant and cause $100 \%$ damage in the plant when not taken under control (EPPO, 2005). Male longevity was observed by Polat et al. (2016) as 3.37-6.14 days while female longevity was 7.7-9.75 days. The total number of eggs per female for each generation varied between 31 and 186 . The females laid $68-72 \%$ of their eggs in the first five days, while data indicated that $81-83 \%$ of the eggs were laid on the $6^{\text {th }}$ day (Polat et al., 2016).

The tomato is grown in many countries but is one of the most important vegetables produced in Turkey where it was ranked fourth in the world in 2016 with 12.600 .000 tons of tomato production and a total plantation area of 180.670 ha (TUIK, 2017). As a major pest, similarly to its global prominence, the tomato leafminer poses a significant threat to tomato cultivation in the province of Çanakkale. It has been determined that $88 \%$ of all tomato growing areas in Çanakkale province are infested with T. absoluta (Polat et al., 2015). 
Comprehensive and alternative control methods should be investigated for use in integrated pest management programs (IPM), especially in terms of issues related to resistance and extensive insecticide use (Polat and Tiryaki, 2019). Among the alternative methods, pheromones are used to monitor the population of insects to identify the correct timing to apply various control strategies, such as the introduction of natural enemies, intensification of mass trapping and application of insecticides (Megido et al., 2013; Braham, 2014). Different types of traps such as water pans and coloured traps also interfere in the attraction of the adults of T. absoluta. This pest has been controlled in many countries in the world by way of IPM programs, based on the use of pheromones and mass trapping applications (Gonzales-Cabrera et al., 2011; Cherif and Lebdi-Grissa, 2014; Aksoy and Kovanc1, 2016; Bayram et al., 2017). On the other hand, light traps have also been used as part of the mass trapping method for pest control (Stol et al., 2009; Cocco et al., 2012; Ozkan et al., 2017). In other research, roll traps were designed to reduce the $T$. absoluta population for tomato growing in greenhouses (Hassan and Alzaidi, 2010). However, these studies were performed with a limited number of traps of different colour and type. In addition, roll traps with pheromones have not been used yet to determine $T$. absoluta in open-field tomato production.

Therefore, the purpose of the present research was to define the efficacy of mass trapping $T$. absoluta with five different colours (red, yellow, blue, white, black) and three different types of trap (ferolite, water pan, roll) in open-field tomato cultivation.

\section{Materials and methods}

\section{Experimental area}

The mass trapping experiments were carried out in 2017 on open-field tomato crops at the villages of Dumrek and Ciplak in the province of Çanakkale located in northwest Turkey (Figure 1, Table 1).

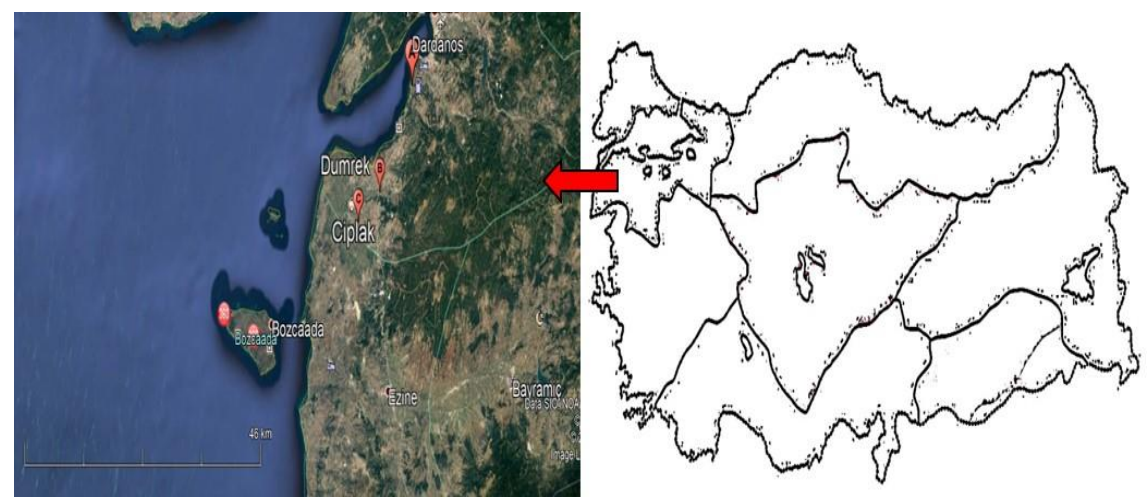

Figure 1. Location of 3 trial areas in study

Tomato was cultivated at Faculty of Agriculture Application Area in Dardanos. In addition, producer-controlled trial parcels were also established in the villages of Dumrek and Ciplak near the site of ancient Troy. Each experimental area was four da in size. The tomatoes were transplanted on 12.05.2017 at Dumrek, on 14.05.2017 at Ciplak, and on 24.05.2017 at Dardanos and the traps were placed on the same days. 
The pest population did not reach an intensity which could result in economic damage and hence no insecticide was applied during the study. Fungicides (Penconazole, Copper oxychloride) were used to ensure the healthy growth of the tomatoes and drip irrigation applied to fulfil their water requirement. Furthermore, the parcels were fertilized according to soil analysis that was carried out at the beginning of the season.

Table 1. Study areas and parcel data

\begin{tabular}{c|c|c}
\hline Study Area & Tomato variety & GPS Coordinates \\
\hline \multirow{2}{*}{ Dardanos } & Lycopersicum esculentum Mill. cv. Troy F1 & $40^{\circ} 429.67^{\prime \prime} \mathrm{N}$ \\
& & $26^{\circ} 21^{\prime} 51.13 \mathrm{E}$ \\
Dumrek & Lycopersicum esculentum Mill. cv. Troy F1 & $39^{\circ} 58^{\prime} 17.05^{\prime \prime} \mathrm{N}$ \\
& & $26^{\circ} 18^{\prime} 4.10^{\prime \prime} \mathrm{E}$ \\
Ciplak & Lycopersicum esculentum Mill. cv. Troy F1 & $39^{\circ} 56^{\prime} 24.42^{\prime \prime} \mathrm{N}$ \\
\end{tabular}

\section{Agricultural applications}

Five different colours (red, blue, yellow, white, black) and three different types of trap (ferolite, water pan, roll) were used for the mass trapping applications. To obtain data on the colour of the traps, a Minolta CR-400 Chroma meter (Konica, Minolta, Japan) was used in the study (Table 2).

Table 2. Colour data used in traps

\begin{tabular}{c|c|c|c|c|c}
\hline Colour of trap & L & a & b & c & Hue \\
\hline White & 65.23 & 0.17 & -3.36 & 3.6 & 272.99 \\
Black & 17.67 & -0.24 & 4.03 & 4.04 & 93.41 \\
Blue & 32.12 & 11.07 & -40.83 & 42.51 & 285.17 \\
Yellow & 76.44 & -6.56 & 79.97 & 80.24 & 94.69 \\
Red & 37.49 & 40.73 & 39.26 & 50.15 & 38.92 \\
\hline
\end{tabular}

The water pan traps (Tutasan, Turkey) and ferolite (with light source, Russell IPM Ltd., UK) used in this study contain pheromone lures (E3, Z8, Z11-Tetradecatrienil). Roll traps (Russell IPM Ltd., UK and Tutasan, Turkey) which make use of high attraction pheromone film were also used. The dimensions of the traps were as follows. The height of the water pan traps from bottom to top was $7 \mathrm{~cm}$ and the diameter was $36 \mathrm{~cm}$. For ferolite traps the lamp height was $30 \mathrm{~cm}$, base length $26 \mathrm{~cm}$, and the diameter $40 \mathrm{~cm}$. To prepare the roll traps, the film was glued on a pipe with a diameter and length of $7.5 \mathrm{~cm}$ and $150 \mathrm{~cm}$, respectively, thereby covering the whole pipe. Traps were placed in the field with four traps per day (Aksoy and Kovanc1, 2016; Cherif et al., 2018). The traps used in the trial were placed in the parcels in the pattern indicated below (Figures 2 and 3).

Adults in the traps were counted twice per week; after that they were removed and the traps were cleaned for the new count. The water level was checked during inspection and the traps were refilled when necessary. Pheromone lures were replaced every four weeks. However, the roll traps were replaced every three weeks due to dryness of the sticky film. 


\section{Statistical analysis}

The data were analyzed by Minitab R18 (StatSoft, Inc. Tulsa OK, USA) statistical software. Differences between the data were evaluated by means of variance analysis (ANOVA) using GLM. Tukey's method was applied as a group comparison test.

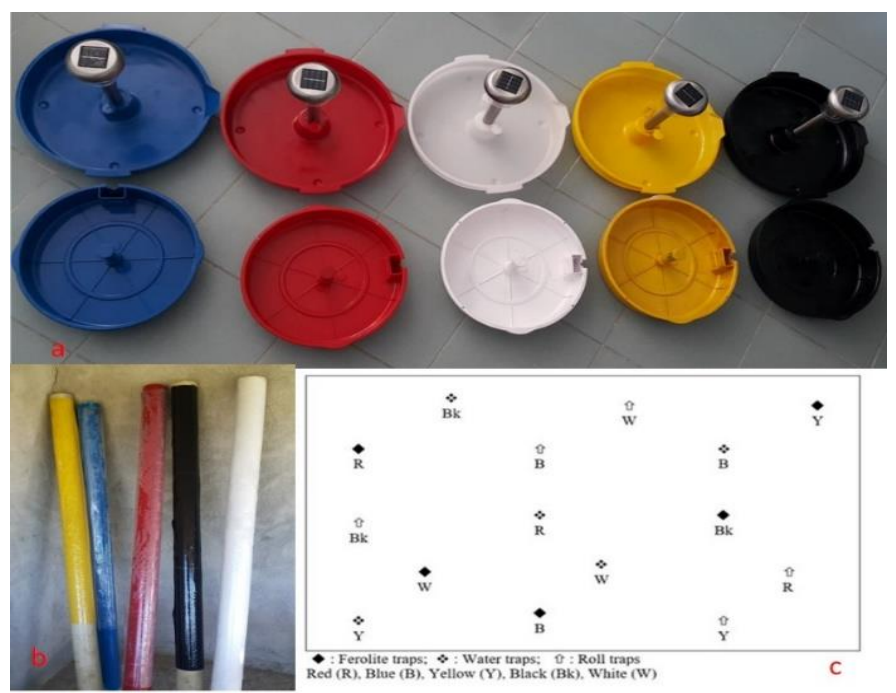

Figure 2. Three different traps used in ferolite and water traps (a), roll traps (b) and their placement pattern (c)

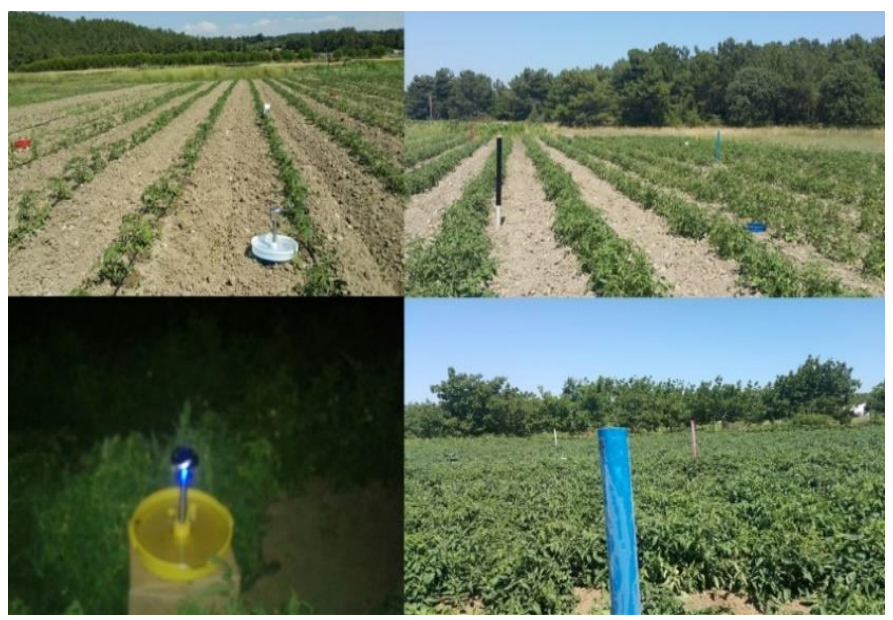

Figure 3. Different traps and colours placed in trial plots

\section{Results and discussion}

The first adult Tuta absoluta at the Dardanos experimental site were trapped on 25.05.2017 when the average temperature was $11.1^{\circ} \mathrm{C}$. The highest number of captured adults in the season was 267 on 24.08.2017 in the white ferolite traps. The proportional average humidity was measured in this 4-day interval (21-24.08.2017) as 75.2\%, while the average temperature was $22.1{ }^{\circ} \mathrm{C}$. The highest total number of adults captured was 3.864 in the white ferolite traps. This was followed by the black ferolite traps with 3.678 and blue ferolite traps with 2.955 adults (Figure 4). 
The first adult at the Dumrek trial area were captured on 18.05.2017 when the average temperature was $17.1^{\circ} \mathrm{C}$. The highest number of captured adults during the season was 401 on 24.08 .2017 in the black ferolite traps. The proportional average humidity was measured in this time interval (21-24.08.2017) as 70.5\%, while the temperature average was $24.6^{\circ} \mathrm{C}$. Overall, the highest total number of adults captured was 4.645 in the white ferolite traps. This was followed by the black ferolite traps with 4.599 and the black water pan traps with 4.520 adults (Figure 5).

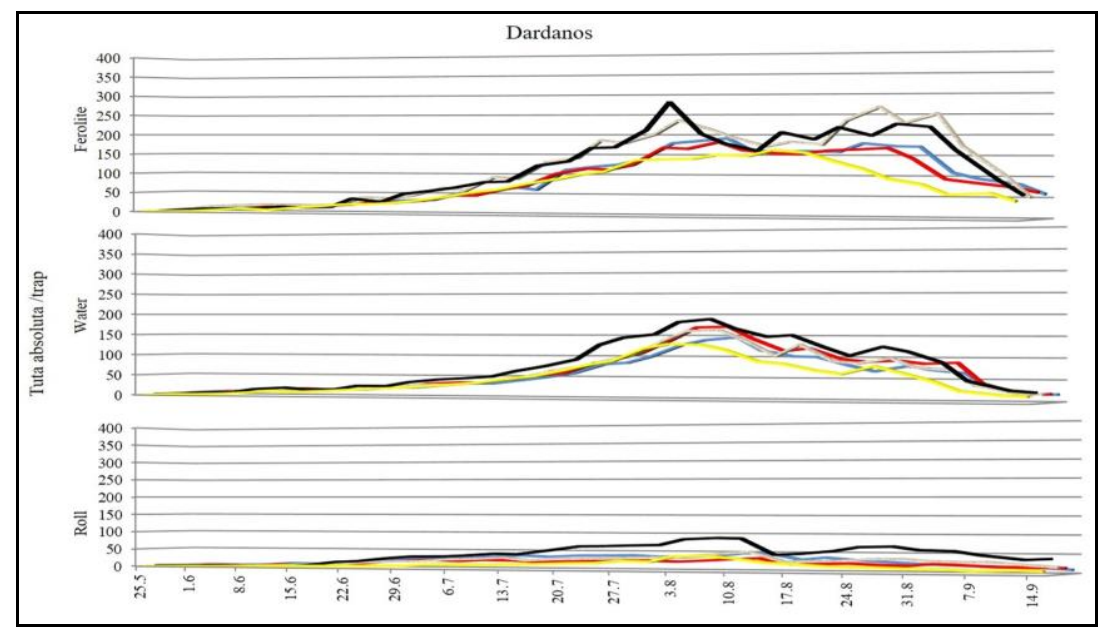

Figure 4. Tuta absoluta captured at Dardanos by type and colour of trap

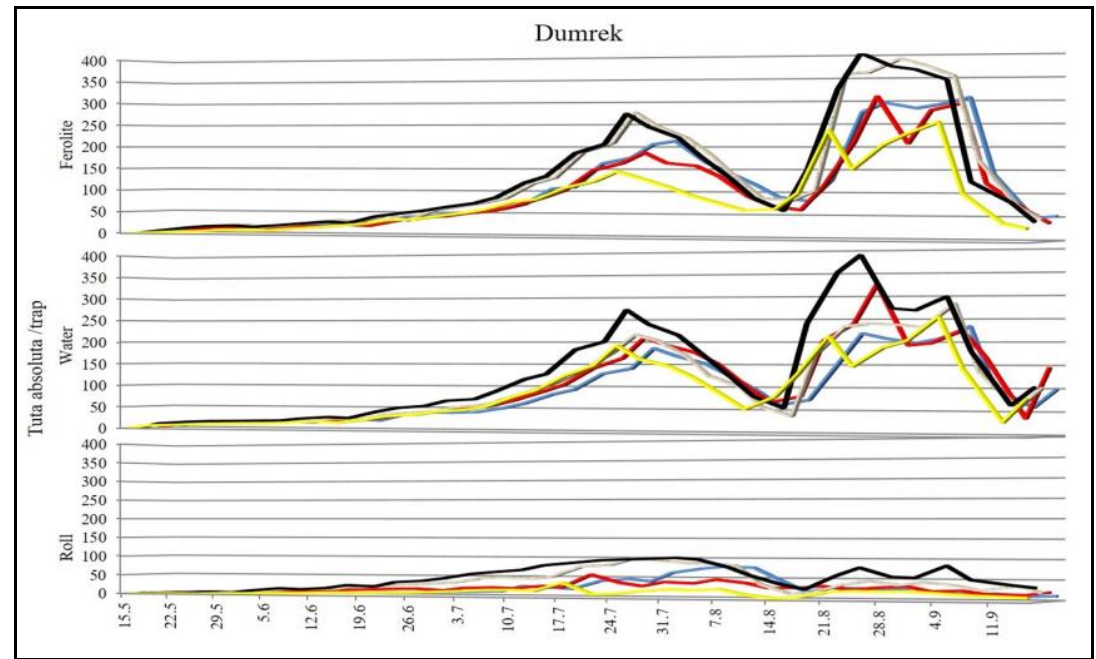

Figure 5. Tuta absoluta captured at Dumrek by type and colour of trap

The first leafminer adults at the Ciplak trial area were captured on 18.05.2017 when the average temperature was $17.1^{\circ} \mathrm{C}$. The highest number of captured adults throughout the season was 282 on 27.07.2017 in the black ferolite traps. The proportional average humidity was measured in this time interval (24-27.07.2017) as 61.2\%, while the temperature average was $22.6^{\circ} \mathrm{C}$. The highest total number of adults captured was 4.028 in the white ferolite traps. This was followed by the black ferolite traps with 3.969 and blue ferolite traps with 3.518 adults (Figure 6). 
A statistically significant difference was determined between the traps based on the adult count $(\mathrm{P}<0.05 ; \mathrm{F}=91.54)$. As can be seen in Figure 7 , a difference was observed between the trap types. In all study areas, ferolite traps were the most successful in catching adults and this was followed by the water pan traps and roll traps. The effectiveness of trap types does not change between different locations. A total of 108.043 T. absoluta adults were captured in the traps. The proportional distribution is given in Figure 8.

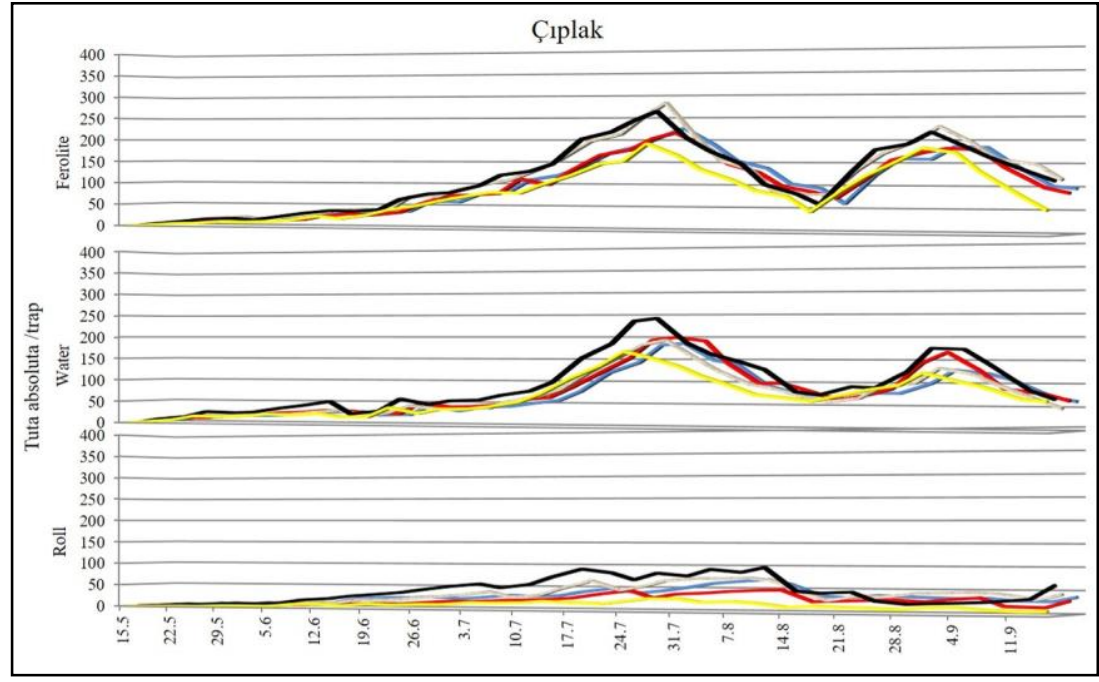

Figure 6. Tuta absoluta captured at Ciplak by type and colour of trap

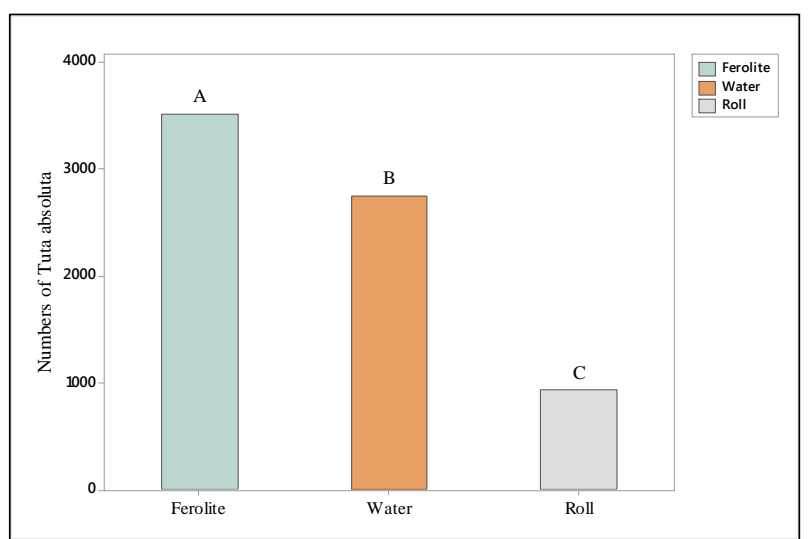

Figure 7. Tuta absoluta captured by different trap type.

*Different letters indicate statistical significance $(P<0.05)$ for in-column comparisons

The highest number of adults was captured in ferolite traps with a total of 52.748 (49\%), followed by water pan traps and roll traps with 41.257 (38\%) and $14.038(13 \%)$ captured adults, respectively. As can be seen in Figure 9, while the highest number of adults among the ferolite traps was captured in white traps (12.537), a statistically significant difference was not determined with those captured in black traps (12.246). The lowest number of tomato leafminer adults was captured in yellow ferolite traps with 8.029. Stol et al. (2009) stated that light traps in greenhouses attract both females and 
males in the struggle against T. absoluta, whereas pheromones attract only males, leading to minimum damage in greenhouses. Similar results were found in studies by Matos et al. (2012) and Özkan et al. (2017) in which it was shown that a greater number of adults were captured with light traps. However, Aksoy and Kovanc1 (2016) carried out a study in which the damage rates were compared for ferolite and water pan traps; as a result of which it was found there is no difference except for the fact that the ferolite trap is not economically feasible since it has a higher unit cost in comparison with the other trap.

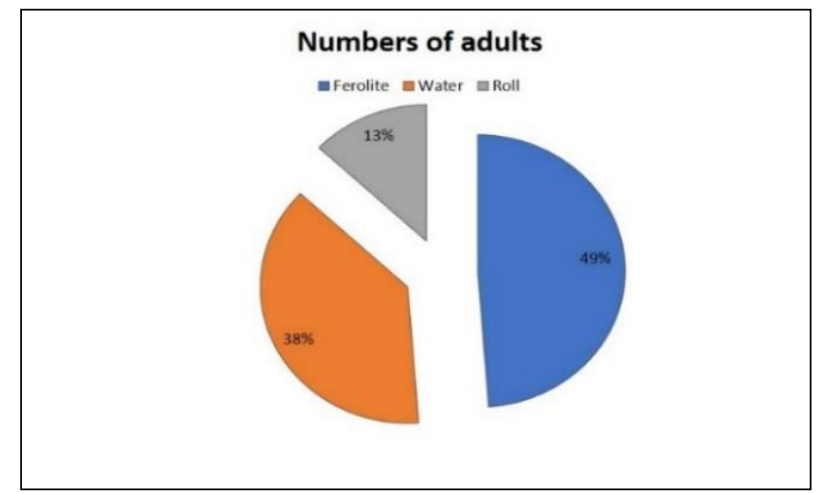

Figure 8. Total number of Tuta absoluta captured by type of traps (\%)

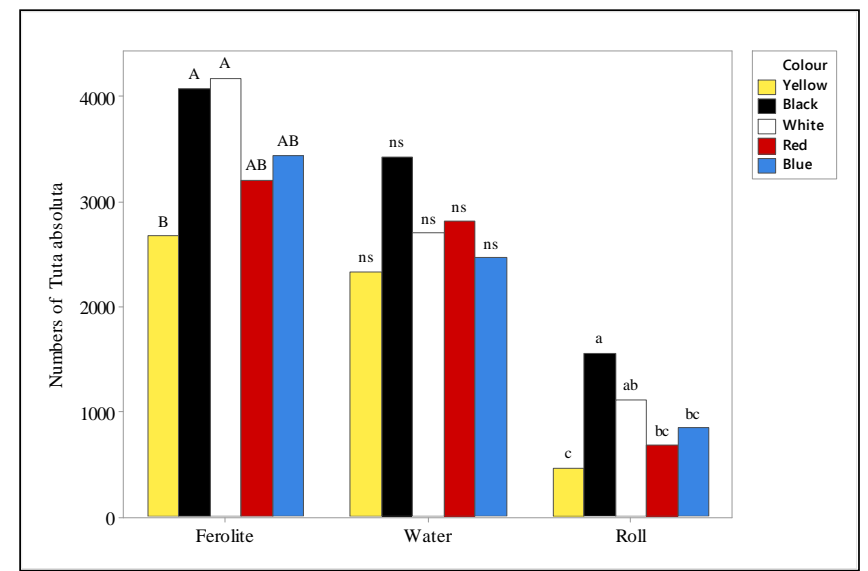

Figure 9. Tuta absoluta captured by type and colour of traps.

*Different letters indicate statistical significance $(P<0.05)$ for in-column comparisons. $n s=$ no significant difference

Despite the lack of a statistically significant difference between the water pan traps, the highest number of adults was captured in black traps with 10.299; this was followed by red, white, blue and yellow traps with 8.441, 8.106, 7.395 and 7.016, respectively. Taha et al. (2012) carried out a study with red, blue, green and yellow traps in which it was found that the highest number of $T$. absoluta adults was captured in the red water pan traps, and sequentially by blue, green and yellow traps, respectively. Similar to the results of Taha et al. (2012), in our study the yellow water pan traps were found the least attractive for adults of $T$. absoluta, whereas red traps were found the most attractive. 
It was observed as a result of analysis carried out based on the colour, independent of trap type, that black and white attracted the highest number of adults whereas yellow attracted the least number of adults $(\mathrm{P}<0.05 ; \mathrm{F}=6.57)$. Mahmoud et al. (2014) found that white and yellow were more attractive, while Shiberu and Getu (2017) reported that the highest number of adults was captured in white and blue sticky traps, whereas the lowest number of adults was captured in green and red traps. These studies show that the white traps have the highest potential to attract $T$. absoluta. A statistically significant difference was observed between the roll traps with the highest number of adults captured in the black trap (4.690). This was followed by white, blue, red and yellow traps with 3.353, 2.550, 2.036 and 1.409, respectively.

Hassan and Alzaidi (2010) reported that yellow rolls can be used to catch T. absoluta but their use is not recommended in greenhouses because yellow traps could also attract beneficial insects. However, yellow was found to have the lowest efficiency for capturing tomato leafminer in all trap types in the current research. Therefore, yellowcoloured traps are not recommended for use in open-field tomato cultivation to capture T. absoluta. On the other hand, more adults were captured in all traps that were black and white. Therefore, black and white traps are highly recommended for attracting T. absoluta in open-field tomato production.

\section{Conclusion}

As a result, the mass trapping method is effective with low pest populations. Even though it is not directly effective in reducing T. absoluta in high pest populations, when it is used together with other control methods, the tomato leafminer population can be kept below harmful economic levels. Consequently, it can also be useful to increase the producer's profits by decreasing the use of insecticides. In addition to its impact on reducing costs, this aspect of the mass trapping method is also important due to the adverse impact that insecticides have on human health and the balance of nature. Also, studying different hues of black and white colours, which were the most effective colours in further researches, would be beneficial to increase the effectiveness of the traps.

Acknowledgements. Financial support from the Scientific Research Projects Committee (Project: FBA 2017/1260) of Çanakkale Onsekiz Mart University, Turkey is gratefully acknowledged.

\section{REFERENCES}

[1] Aksoy, E., Kovanci, O. (2016): Mass trapping low-density populations of Tuta absoluta with various types of traps in field-grown tomatoes. - Jour. of Plant Dis. and Prot. 123: 51-57.

[2] Bayram, Y., Duman, M., Buyuk, M., Mutlu, C. (2017): Effciency of pheromone water traps and life cycle of Tuta absoluta (Lepidoptera: Gelechiidae) in Diyarbakır province, Turkey. - Fresen. Environ. Bull. 26: 531-538.

[3] Braham, M. (2014): Role of trap colours and exposure time of pheromone on trapping efficacy of males of the tomato leaf miner, Tuta absoluta (Meyrick) (Lepidoptera: Gelechiidae). - African Journal of Agricultural Res. 29: 2263-2271.

[4] Cherif, A., Harbaoui, K., Zappalà, L., Grissa-Lebdi, K. (2018): Efficacy of mass trapping and insecticides to control T. absoluta in Tunisia. - J. Plant. Dis. Prot. 125: 51-61. 
[5] Cocco, A., Deliperi, S., Delrio, G. (2012): Potential of mass trapping for Tuta absoluta management in greenhouse tomato crops using light and pheromone traps. - IOBC WPRS Bull. 80: 319-324.

[6] Desneux, N., Wajnberg, E., Wyckhuys, K. A. G., Burgio, G., Arpaia S., NarváezVasquez, C. A., González-Cabrera, J., Ruescas, D. C., Tabone, E., Frandon, J., Pizzol, J., Poncet, C. (2010): Biological invasion of European tomato crops by Tuta absoluta: ecology, geographic expansion and prospects for biological control. - Journal of Pest Science 83: 197-215.

[7] EPPO (2005): Data sheets on quarantine pests, Tuta absoluta. - EPPO Bulletin 35: 434435.

[8] Gonza'lez-Cabrera, J., Molla', O., Monto'n, H., Urbaneja, A. (2011): Efficacy of Bacillus thuringiensis (Berliner) in controlling the tomato borer, Tuta absoluta (Meyrick) (Lepidoptera: Gelechiidae). - Biocontrol 56: 71-80.

[9] Gozel, C., Kasap, I. (2015): Efficacy of entomopathogenic nematodes against the Tomato leafminer Tuta absoluta (Meyrick) (Lepidoptera: Gelechiidae) in tomato field. - Turk J. Entomology 39: 229-237.

[10] Hassan, N., Al-Zaidi, S. (2010): Tutaroll - an innovative solution for Tuta absoluta. - Int. Pest Control 52: 262-264.

[11] Kasap, İ., Gözel, U., Özpınar, A. (2011): A new pest in tomatoes; the tomato borer, Tuta absoluta (Meyrick) (Lepidoptera: Gelechiidae). - Çanakkale Agriculture Symposium Past, Present, Future, 10-11 Jan 2011, Çanakkale: 284-288. (In Turkish).

[12] K1lıç, T. (2010): First record of Tuta absoluta in Turkey. - Phytoparasitica 38: 243-244.

[13] Mahmoud, Y. A., Ebadah, I. M. A., Abd-Elrazik, A. S., Tabd-Elwahab, E., Deif, S. H. (2014): Efficiency of different colored traps baited with pheromone in capturing tomato adult moth, Tuta absoluta (meyrick) (Lepidoptera: Gelechiidae) during summer plantation. - World Applied Sciences Journal 30(4): 406-412.

[14] Matos, T., Figueiredo, E., Mexia, A. (2012): Sexual pheromone traps with light for mass trapping of Tuta absoluta (Meyrick), yes or no? - Rev Cienc Agrar 35: 282-286.

[15] Megido, R. C., Haubruge, E., Verheggen, F. J. (2013): Pheromone-based management strategies to control the tomato leafminer, Tuta absoluta (Lepidoptera: Gelechiidae). A review. - Biotechnology, Agronomy, Society and Environment 17: 475-482.

[16] Özkan, Z., Ünlü, L., Ögür, E. (2017): Örtü altı domates yetiştiriciliğinde domates güvesi (Tuta absoluta Meyrick)'ne karşı kullanılan feromon ve ferolite tuzaklarının etkinliğinin karşılaştırılması. - Harran Tarım ve Gıda Bilimleri Dergisi 21(4): 394-403. (In Turkish).

[17] Polat, B., Özpinar, A., Şahin, A. K. (2015): Çanakkale ilinde Domates güvesi (Tuta absoluta (Meyrick 1917), (Lepidoptera: Gelechiidae))'nin konukçularının belirlenmesi. Bitki Koruma Bülteni 55: 331-339. (In Turkish).

[18] Polat, B., Özpinar, A., Şahin, A. K. (2016): Studies of selected biological parameters of tomato leafminer Tuta absoluta (Meyrick), (Lepidoptera: Gelechiidae) under natural conditions. - Phytoparasitica 44: 192-202.

[19] Polat, B., Tiryaki, O. (2019): Determination of some pesticide residues in conventional grown and IPM- grown tomato by using QuEChERS method. - J. of Envir. Science and Health Part B-Pesticides Food Contaminants and Agricultural Wastes 54(2): 112-117.

[20] Portakaldal1, M., Öztemiz, S., Kütük, H., Büyüköztürk, D., Çolakateş, A. (2013): Distribution of Tuta absoluta (Meyrick) (Lepidoptera: Gelechiidae) in the Eastern Mediterranean and Southeastern Anatolia Regions. - Turkish Bulletin of Entomology 3(3): 133-139.

[21] Shiberu, T., Getu, E. (2017): Evaluation of colored sticky traps for the monitoring of Tuta absoluta Meyrick (Lepidoptera: Gelechiidae) in tomato under glasshouse in Ethiopia. Agri. Res. Tech. 9(3): 555762.

[22] Stol, W., Griepink, F. C., Deventer, P. V. (2009): Tuta absoluta: A new pest for tomato growing in Europe. - 2nd. Conference on Pheromones, Food Lure, Traps and Biological Control: Alternatives for The 21st Century Murcia, 18. 
[23] Taha, M., Homam, H., Afsah, E., EL-Sharkawy, M. (2012): Effect of trap color on captures of Tuta absoluta moths (Lepidoptera: Gelechiidae). - Int. J. Environ. Sci. Eng 3: 43-48.

[24] Torres, J. B., Faria, C. A., Evangelista, W. S., Pratissoli, D. (2001): Within-plant distribution of the leaf miner Tuta absoluta (Meyrick) immatures in processing tomatoes, with notes on plant phenology. - International Journal of Pest Management 47: 173-178.

[25] TUIK (2017): Turkish Statistical Institute. - http://www.tuik.gov.tr, Accessed: January 2018.

[26] Urbaneja, A., Vercher, R., Navarro, V., García Marí, F., Porcuna, J. L. (2007): La Polilla del Tomate, Tuta absoluta. - Phytoma Espaňa 194: 16-23.

[27] Uzun, F., Birgücü, A. K., Karaca, İ. (2015): Determination of oviposition preference of Tuta absoluta to tomato, pepper and eggplant. - Asian Journal of Agriculture and Food Science 3(5): 569-578.

[28] Zappalà, L., Biondi, A., Alma, A., Al-Jboory, I., Arno, J., Bayram, A., Chailleux, A., ElArnaouty, A., Gerling, D., Guenaoui, Y., Shaltiel-Harpaz, L., Siscaro, G., Stavrinides, M., Tavella, L., Vercher Aznar, R., Urbaneja, A., Desneux, N. (2013): Natural enemies of the South American moth, Tuta absoluta, in Europe, North Africa and Middle East, and their potential use in pest control strategies. - Journal of Pest Science 86: 635-647 